\title{
Youth involvement: Empowerment effort through child-friendly village program
}

\section{Keterlibatan pemuda: Upaya pemberdayaan melalui program kampung ramah anak}

\author{
Erma Kusumawardani \& Serafin Wisni Septiarti \\ Department of Non Formal Education, Faculty of Education, Universitas Negeri Yogyakarta \\ Address: Jalan Colombo No.1, Sleman, Yogyakarta 55281 \\ E-mail: ermakusumawardani@uny.ac.id \& swisni@uny.ac.id
}

\begin{abstract}
This study aimed to describe activity within the child-friendly village program youth through participatory activities and youth empowerment. This research is a qualitative approach with a grounded theory method and setting of the research activity is the youth of the Tegalrejo District. Informants in this study include both youth and community leaders. The data collected through means of observation, documentation, and interviews. The data analysis technique used is the interactive analysis. Triangulation is done to explain the validity of the data from various sources. These results indicate that youth empowerment includes: a) the reason for the involvement of the youth including recreational interests, concern for the community, self-awareness, a stepping stone to the level of education, job readiness, and as a form of worship, b) youth empowerment seen from planning, implementation, evaluation, and even development, and c) factors supporting the involvement of the youth, their self-awareness and the support of administrators and community leaders. While the inhibiting factors such as the differences in leisure time, the impact of youth empowerment seen from the personal, academic, and vocational skills gained. Therefore, child-friendly village program it can be one of effort. To conclude, in addition to the youth program from the government, the child-friendly village program is seen to increase youth empowerment. Empowerment showed in the impact of youth involvement in the activities of the child-friendly village program.
\end{abstract}

Keywords: empowerment; youth involvement; child friendly village

\begin{abstract}
Abstrak
Penelitian ini bertujuan untuk mendeskripsikan bentuk kegiatan dalam program kampung ramah anak melalui kegiatan partisipatif pemuda dan pemberdayaan pemuda. Penelitian ini menggunakan pendekatan kualitatif dengan metode grounded theory. Setting penelitian aktivitas pemuda di Kampung Tegalrejo. Informan dalam penelitian iniadalah pemuda-pemudidan tokohmasyarakat. Pengumpulandatadenganmenggunakanobservasi, dokumentasidan wawancara. Teknikanalisis datayang digunakan yaituanalisis interaktif. Triangulasi dilakukan untuk menjelaskan keabsahan data dengan berbagai narasumber dalam mencari informasi yang dibutuhkan. Hasil penelitian ini menunjukan bahwa pemberdayaan pemuda meliputi a) alasan keterlibatan pemuda yaitu kesamaan hobi, kepedulian terhadap masyarakat, kesadaran diri, batu loncatan ke jenjang pendidikan, kesiapan kerja, dan sebagai bentuk ibadah b) pemberdayaan pemuda dilihat dari tahap perencanaan, pelaksanaan, evaluasi hingga pengembangan c) faktor pendukung keterlibatan pemuda, adanya kesadaran diri dan dukungan dari pengurus dan tokoh masyarakat. Sedangkan faktor penghambat, perbedaan waktu luang para pemuda d) dampak dari pemberdayaan pemuda ini dilihat dari kecakapan personal, kecakapan akademik, kecakapan vokasional dan kecakapan sosial. Sehingga dapat disimpulkan bahwa selain program kepemudaan dari pemerintah, program kampung ramah anak dapat menjadi salah satu upaya untuk meningkatkan keberdayaan pemuda. Keberdayaan tersebut dapat dilihat dari dampak keterlibatan pemuda di kampung ramah anak.
\end{abstract}

Kata kunci: pemberdayaan; keterlibatan pemuda; kampung ramah anak

\section{Introduction}

Youth became the driving force of the entire series of historical events and the main actor in Indonesia. Even one of the leading Indonesians, Anderson (1991:26) once said that the history of Indonesia is the history of youth. Anderson's statement seemed appropriate. Because if there is no interference of youth in the history of the struggle of the Indonesian nation, today Indonesia is still constrained 
by the colonialism and dictatorship and injustice of other countries. Youth are human beings who have toughness and high spirit in fighting for the revolution and development of the nation towards a better direction. Youth acts on the values of idealism and morality, given the existing resources for the competence of the country. The potential of youth lies like popularizing moods and hearts. Without the youth is not the only one, but the youth remain at the forefront. Youth have a very central and strategic role in every age. So no wonder first the President of Indonesia, Mr Ir. Soekarno said:

$$
\text { “.... for me, one young man, will undoubtedly shake the world." }
$$

According to statistics data from Kemenpora (2010:22) the number of Indonesian youth (population aged 16-30 years) around 57.81 million people or $25.04 \%$ of the total population of Indonesia which amounted to 230.87 million people. The smallest percentage of youth compared to the population under the age of 16 years $(30.88 \%)$ and population over 30 years $(44.08 \%)$. The percentage of urban youth (26.68 percent), is higher than in rural areas $(23.50 \%)$. The sex ratio of youth recorded at 98.00. It means that on average for every 100 young women there are about 98 male youths. The age structure of youth shows that the 16-20 year age group is the most significant component of youth with a percentage of 34.56 percent, followed by youth in the 26-30 years age group (34.00\%), and the 21-25 age group (31.44\%). The overall data above can see that the percentage of youth is lower than other age groups, but in the hands of the younger, the flow of civilization moves becomes better or worse. Youth is an economic asset in the development and economic development in Indonesia; it is related to the age, energy, and thinking ability of the youth. Youth groups are considered to be of productive age, potentially entering the workforce compared to other population groups.

In addition to the potential of the youth, youth who are part of the community cannot be separated from the problem. The problem of youth is both a global issue and a probable issue because it touches the social and cultural values of a society in all parts of the world. The problems of youth that emerged in Indonesia ranging from unemployment, mental crisis, a crisis of existence to moral decadence. Based on self-observation from several cases in the community, the ethical dilemma that engulfed the youth of Indonesia became an obstacle to the progress of the Indonesian nation because the youth have a central and strategic role in the development of a country. The moral crisis of youth is evident from the increasingly rampant youth activities leading to harmful and criminal activities, such as the action of vandalism, brawl, drug party to act immorally. Today's youth have lost their way, far from what the founders of the nation hoped for with their noble goals and ideals. The young man pinned on his shoulder of leadership, now powerless, not as good as before, not as good as an eagle that grips the principles of the nation.

In the other hand, the researcher observes any cases with the effect of technology. It can be seen, in this era of globalization changes information technology and foreign culture become one of the triggers of youth problems in Indonesia. Increasingly sophisticated communication technology is changing the behaviour of youth in the community. The existence of such communication technology, the distance is not a problem in socializing for the youth. So that there is a change in the form of socialization that was looking for peers around the place of residence, replaced by looking for people who have the same interests and hobbies in cyberspace.

Permission culture and pragmatism are increasingly making some young people trapped in hedonistic life, instantaneous, and uprooted from the idealism that tends to be anti-social human (Kemenpora 2009). The culture seemed to indoctrinate the youth to move away from the culture in Indonesia. The lifestyle like the westerners who are no longer taboo in Indonesia. Youth activities and activities tend to oriented to western culture. Such as, irreverent ways of dressing that should not use until the way they get along. Formerly in our culture, it was essential for the manner of dress that was polite and closed. However, due to the influx of foreign cultures, the culture changed. Now dressed as opening genitals seems to have become a habit that deeply embedded in our society. So forget about the clothes that should be worn by the Indonesian people. From that trend, many cases of juvenile delinquency increasingly spread in the mass media, both print and electronic. See from recent cases such as dropping out of school, vandalism, immoral acts, free sex, unwed pregnancy, the brawl 
between students, even brawl between supporters of the majority of the time is a young man who is labelled the next generation of the nation.

Yogyakarta Special Region is a city of education is often also referred to as a student city. From the statement shows that the Special Region of Yogyakarta has more youth than other cities in Indonesia. According to Utaryo on news article from Bantul District Government (2012) from Yayasan Sayap Ibu Yogyakarta when delivering his presentation in the Children's Decent People Socialization, delinquency case in Yogyakarta Special Region has been very severe, such as school brawl, the teenage brawl between villages, drunkenness, drugs, inconsiderate, school children pregnant out of wedlock and so on. So the brawl case seems to have become a culture that is done regularly in Yogyakarta Special Region.

A large amount of youth in the city of Yogyakarta does not make a surprise if frequent brawl. Based on data from Polresta Yogyakarta (Antara 2013), shows that the number of student violence in Yogyakarta City is increasing. Violence cases involving students in 2011 accounted for nine cases, and there have been three cases delegated to the prosecutor's office and six other cases ended in peace. While in 2012 there were five cases with two cases delegated to the prosecutor's office while the rest ended peacefully. Meanwhile, five violent cases involving students from 2013 to May occurred in five sub-districts in Yogyakarta: 1) the first case occurred in Gondokusuman District involving student gangs from two schools, and now the case is still under investigation, 2) the second case occurred in Umbulharjo sub-district involving students from two private schools and the case ended peacefully, 3) the next case occurred in the District of Jetis is throwing Molotov cocktail to the security guard post of a vocational high school. In that case, the Police of Yogyakarta arrested 21 people, but those who were found to have thrown the Molotov cocktail and then designated the suspect were four, 4) cases of violence involving learners also occurred in the District Mantrijeron. Local police are still processing the case, and 5) a similar case also occurred in Tegalrejo District. Police continue to hunt the perpetrators of violence.

Similar problems that occurred in recent years in the city of Yogyakarta is the action of vandalism. The perpetrators of this vandalism action are none other than the young. Action scratching and attachment of any brochure mostly found in the corner of the city of Yogyakarta both on the roadside and the centre of the crowd. Vandalism action often found in the walls and doors of shops, public places, tourist attractions and even on public transport as can be seen along the road 'gejayan' and Malioboro road. Even up to the centre of the crowd like the zero points that until now still found streaks from the youth. In June 2014, the Department of Order (Dintib) Yogyakarta managed to capture 19 perpetrators of vandalism. Nineteen perpetrators of vandalism were two of them processed in court and subjected to minor criminal acts. While the other 17 are still underage (seventeen years and under) so that only done coaching (Handito 2014).

In article 16 of Law No. 40 of 2009 on Youth, "Youth plays an active role as a moral force, social control and change agents in all aspects of national development". Youth is a human resource in the development and future leaders. Youth is not only the responsibility of the government or the community but the responsibility of society with the government. So it should be youth development should be a necessity to support the achievement of human resource development. Youth become the appeal of the government to assist development efforts. The development of various potentials owned by the youth such as talents, abilities, and interests is needed to be more beneficial for himself and the surrounding environment. Empowerment activities are the implications of community-based development strategies, including youth. Community empowerment is a process of improving the ability and attitude of community self-reliance (Totok \& Poerwoko 2013:28). So that empowerment activities provide opportunities for individuals to proceed to develop the ability to be more empowered. Efforts of empowerment became one of the appropriate steps to be given to the youth. Given the potential of youth, the youth need to be empowered to be more capable and independent develop themselves.

To reduce cases of violence and vandalism by youth, the Office of Youth and Sports Education (Disdikpora) of Yogyakarta City formed a forum for a youth organization. Education is required to 
have relevance to needs and face developments, to be able to provide provisions for life in community life. Education is a factor that is directly related to youth considering the young age is school age (Tirtosudarmo 1994:20). With the youth organization, it expected that teenagers would not easily fall into the negative influence that can trigger negative things. However, the reality, because of the rapid influence of science and technology on youth, is now rarely encountered in youth organizations in the community, especially in urban areas. It is overcoming the government's efforts not only through youth organizations only. Local governments have several programs that do not exclude the possibility of involving youth. In 2010, the government of Yogyakarta City through the Minister of Women's Empowerment regulation no. 2 of 2009 on District/City Planning Policies Children pioneered child-friendly village program. Child-friendly village program is still warmly discussed by the community. The program can be used as a platform for youth to channel potential and minimize harmful activities that lead to delinquency to crime. Also, this program can be a stepping stone for the youth to organize the future.

\section{Research Method}

This research is a qualitative approach with the grounded theory method. According to Sugiyono (2013), qualitative research methods are research methods based on the philosophy of post-positivism, used to examine the condition of natural objects. Setting the research activity of youth in Tegalrejo Kampong. There is 14 informant in this study from youth and community leaders. The research was the main instrument in conducting research that assisted with guidelines - the collection of data by using observation, documentation, and interview. The data analysis technique used is an interactive analysis. Triangulation is done to explain the validity of the data from various sources to find the information needed.

\section{Results and Discussion}

Young people based on biologically are those who are in the phase of childhood and adulthood (16-30 years) and have similar historical experiences in society (Abdullah 1974). Youth empowerment is the process of improving, developing, and strengthening the potential and power of the youth in achieving independence. Youth is a human resource in the development and future leaders. The development of various potentials owned by the youth such as talents, abilities, and interests saga needed to be more useful for themselves and the surrounding environment. The dimensions of empowerment program management are: 1) activities undertaken by a manager along with other people or groups, 2) activities carried out jointly and through the person has a goal to be achieved, and 3) done in an organization so that the goals achieved are the goals of the organization. Empowerment is the power to act and a process to expand and improve the capacity of people (individuals or groups) as a strategic choice to get the desired result (Rustinsyah 2018). Whereas according to Suparjan \& Suyatno (2003:43), empowerment has the meaning of generating resources, opportunities, knowledge, and skills of the community to increase capacity in determining their future. Youth empowerment through this child-friendly village program has a common goal to be achieved for the welfare of organizations and communities, especially youth. This empowerment activity is conducted through a structured organization and has a series of programs and activities involving youth as a leader. This youth empowerment activity is not much different from the empowerment activity in general, but it can not deny that there is little difference in the process because youth has different characteristics from other times. Also, youth involvement in this empowerment effort is slightly different. Youth in general in the process of empowerment as a member, but to empowerment through this child-friendly village program the youth involved in the management.

The resulting research from Suharta \& Septiarti (2018), child-friendly village program is a concept developed by the Yogyakarta city government to fulfil the right to live, learn, protect, and participate in development. Culturally, the community responds with the principle of togetherness, commitment, integrating the meaning of child-friendly in the form of various activities involving parents, young people, and community leaders. So, The involvement youth in a child-friendly village program is inseparable from the reasons behind the youth's willingness to engage. The reasons for youth 
involvement are 1) Self-awareness, 2) Hobby equality, 3) awareness of society, 4) Stepping stone to continue education, 5) Readiness of work, and 6) As a form of worship. Six functions of program management, according to Sudjana (2004:53) have the following order of planning, organizing, mobilization, coaching, assessment, and development. Child-friendly village program certainly deals with the workaround of program management. Youth empowerment through a child-friendly village program has a series of management processes traversed. Empowerment includes the components of macro learning model and component model of special skills learning (micro) in the form of training. The macro learning component consists of awareness, planning, organizing, mobilization, assessment, and development.

Implementation of youth empowerment through child-friendly village program by youth through several stages of planning, implementation, evaluation, and development. It can be understood from the involvement of youth in the implementation of child-friendly village program. Forms of youth involvement are: 1) needs analysis and activity plan, 2) motor drive in the implementation of activities, 3) evaluation of activities, and 4) development of activities. The activity needs analysis to see the needs of the children. Needs analysis activities done by collecting data on children on hobbies, interests, learning difficulties of children to problems facing children. From the data then analyzed as a material for the preparation of child-friendly village activities. After the activities have established, youth organize a children's forum to review that the activities prepared are acceptable to the children and address the needs of the children. The last stage of the planning process is consultation. This consultation conducted with teams during regular meetings. However, it did not rule out the consultation carried out personally. The purpose of this consultation is to ensure that the activities to be carried out receive the approval and support of leaders.

The involvement of youth in the implementation stage is as the driving force of the activities that have planned previously. Youth organize the flow of child-friendly village activities. The activities include: 1) particular protection cluster: socialization of child-friendly villages, slogan placements and child-friendly village culture, environmental improvement and drug education, 2) educational clusters and leisure time utilization: joint learning, magazine making, dance training, early childhood education or Pendidikan Anak Usia Dini-PAUD, Al-Quran education centre or Tempat Pembelajaran Al-Quran-TPA and sports, 3) cluster of civil rights and freedoms: children's data collection, provision of children's forums and regular meetings with administrators, 4) essential health and welfare cluster: posyandu, checking mosquito larvae and reproductive socialization for teenagers, and 5) family environment cluster and alternative care: Family Development or Bina Keluarga Balita-BKB.

In the implementation stage, youth divide labour. The division of labour is like a host, guide, documentation, equipment, consumption, and public relations. Also, youth coordinate with older elders who also serve as community leaders. Coordination is done to get support in every action that youth do to achieve the goals of the activities undertaken for children. Jennings et al. (2008:31-55) draws upon analysis of four youth empowerment models, and upon findings from a participatory research study which identified critical dimensions of critical youth empowerment: 1) a welcoming, safe environment, 2) meaningful participation and engagement, 3) equitable power-sharing between youth and adults, 4) engagement in critical reflection on interpersonal and sociopolitical processes, 5) participation in sociopolitical processes to affect change, and 6) integrated individual -and community-level empowerment. Casimir (2009) add some understanding about youth involvement that can be seen from participation from young people. Participation of young people viewed from the following three perspectives. The basic level of participation is a 'member' with a sense of engagement and belonging. The second level pertains to participation in the sense of having a voice, expressing a view and having it listened to, and participating in decision-making. The third level refers to opportunities for young people to participate and contribute to the development of the community and civil society. So, this research will see the youth empowerment from the youth involvement at the child-friendly village program.

Involvement in the last stage is the evaluation of child-friendly village activities. This evaluation is carried out by giving each other inputs for improvement in child-friendly village activities that 
have not been implemented. Evaluation activities carried out immediately completed activities but sometimes also performed at regular meetings of the community team. After conducting an evaluation, the next youth involvement is in developing a child-friendly village program. Forms of youth development are starting from making fund proposal for child-friendly village development, planning, implementation until the evaluation of child-friendly village development activity and making accountability report of fund and activity to parties cooperating with the child-friendly village. In the development, the planning stage of the activity divided into two forms, namely the preparation of new activities and the development of previous activities.

In addition to having a supporting factor also has an inhibiting factor. The inhibiting factor is the difference in spare time. So that resulted in the youth cannot be maximally in carrying out the duties and roles of a child-friendly village. This result same as Pearrow (2008) that add about training for youths prioritize community concerns and then examine societal values, institutional policies, using the Social Change Wheel. Represents four interrelated factors of societal dynamics, and the youths examine these factors and generate strategies to change these dynamics. Casimir (2009) add about the challenges of youth participation and the reasons for non-participation of young people are 1) young people not included, or adults, 2) dominate them participation is denied for lack of knowledge, and formal and non-formal spaces restricted or denied, and 3) the youth themselves withdraw or are forced to give up for lack of acceptance and opportunities. So, youth empowerment that will change social dynamics in the environment will be affected some factors that mention in that Mellisa research.

The youth empowerment effort through the child-friendly village program has had a positive impact on youth. According to Ambar (2004:80), the purpose of empowerment is to form an individual and an independent society. That independence includes the independence of thinking, acting, and controlling what they do. Therefore, the impact of empowerment is closely related to increased insight and skills/life skills. The Broad-Based Education Team (2002:10) states that understanding life skills is broader than skills to work. People who do not work, such as housewives or retired people, still need life skills. Like people who work, they also face various problems that must be solved. People who have gone through education also need life skills because they certainly also have their problems. According to Ditjen Diklusepa (2003:7), the skills grouped into four, namely 1) personal skills, 2) academic skills, 3) social skills, and 4) vocational skills. The result of Russell et al. (2009) gives more understanding about three inter-related dimensions of youth empowerment: personal empowerment, relational empowerment, and strategic empowerment through having and using knowledge. When these three dimensions experienced in combination, the leaders have the potential for individual and collective empowerment as agents of social change at school. By understanding these youth's perspectives on the meanings of empowerment, this article clarifies the conceptual arena for future studies of socially marginalized youth and of positive youth development. Morton \& Montgomery (2012) added about Assess the state of evidence regarding impacts of youth empowerment programs (YEPs) on adolescents' (ages 10-19) self-efficacy and self-esteem, as well as other social, emotional, and behavioural outcomes. Therefore, the impact of youth empowerment can be seen in many aspects. Such as from personal and group of youth.

Based on the results of the research, youth benefited greatly from involvement in child-friendly village program. In terms of personal skills that youth have an understanding of their potential and interest or interest, youth have the courage and independence and increased problem-solving that is rational. In terms of academic proficiency, the increasing knowledge of youth, especially about the child-friendly village, the increasing insight on how to organize in society and the high motivation to continue the education level and the attitude of competition in achieving the achievements.

In terms of vocational skills that the youth can speak in public. The ability can be seen when delivering presentations on child-friendly village profiles and when young and young dare to host the activities of the child-friendly village and the other activities in the district. Also, young people have skills in conceptualizing events in child-friendly village activities. The concept of child-friendly village activities is simple but different from others, so it becomes an attraction for the community. Finally, 
in terms of social skills, youth become actively helping in all activities, youth can establish excellent communication with the community, and the youth have many relations in the neighbourhood until relation from another institution.

The conclusions can be found from the discussion on youth involvement in the implementation of child-friendly village program by the expected objectives. According to Ayusia (2011) based on a critical perspective on youth empowerment it has six dimensions of the success of the youth empowerment process namely 1) friendly and safe environment, 2) engagement and commitment, 3) fair distribution of power, 4) engagement with reflection in interpersonal and social-political processes, 5) social and political involvement in making changes, and 6) integrated in empowerment at the individual and community level.

Therefore, the condition of success of youth empowerment is that it can create a friendly and safe environment and can involve the active participation of youth in all fields as well as increase the level and ability individually and in groups. It means the involvement of youth in the implementation of the child-friendly village program, which starts from the stage of awareness. Then the youth involved from planning to development. The involvement of youth in the implementation of child-friendly village campaigns can have a positive impact on youths who are involved in child-friendly village management. The stages of organizing the child-friendly village program performed well and gave deep meaning to the youth. However, there are still obstacles in youth involvement being a challenge for youth. The challenge is to maximize the performance of the mentor to fit the task and role. The second challenge is to mobilize other youth also to be involved in organizing a child-friendly village program.

\section{Conclusion}

The form of youth empowerment conducted by community leaders for the youth is by involving youth in the child-friendly village program. The reason for the involvement of youth in the management of child friendly village program is 1 ) the existence of self-awareness, 2) the similarity of hobbies, 3 ) the awareness of the community, 4) the springboard for continuing education, 5) readiness of work, and 6) as a form of worship. Implementation of youth empowerment through child-friendly village program by youth through several stages of planning, implementation, evaluation, and development. The involvement of youth in the planning phase includes the analysis of needs and the preparation of activities, furthermore, in the implementation stage of youth as the motor of an activator of activity. Youth were involved in the evaluation phase by providing inputs for improvement of activities childfriendly village and the last of the youths involved in the development of the child-friendly village program. Based on the results of the research, activities in child-friendly village program have implemented by the guidelines and implementation guidelines. The existence of youth involvement is the result of youth empowerment through child-friendly village program. In general, not all youth can be said to be empowered because not all youth have the same sense of belonging to the childfriendly village program. The young man who contributed a lot to the child-friendly village program has independence and different skills with other youth.

\section{References}

Abdullah T (1974) Pemuda dan Perubahan Sosial. Jakarta: LP3ES.

Ambar T (2004) Kemitraan dan Model-model Pemberdayaan. Yogyakarta: Gava Media.

Anderson B (1991) Imagined Community: Reflection On The Origin and Spread of Nationalism. Ithaca: Cornell University Press.

Antara (2013) Angka Kekerasan Pelajar di Yogyakarta Meningkat. [Accessed 25 January 2019]. https://www.republika.co.id/berita/nasional/jawa-tengahdiy\%20nasional/13/05/22/ mn6wwr-angka-kekerasan-pelajar-di-yogyakarta-meningkat.

Ayusia K (2011) Mengawali Perbincangan tentang Pemberdayaan Pemuda. [Accessed 13 November 2015]. https://www.sosbud.kompasiana.com.

Casimir RM (2009) Youth Empowerment Through Participation. https://www.researchgate.net/ publication/282905598_Youth_Empowerment_through_Participation. 
Ditjen Diklusepa (2003) Pedoman Umum Pelaksanaan Program Pendidikan Berorientasi Keterampilan Hidup (Life Skills). Jakarta: Ditjen Diklusepa.

Handito DN (2014) 19 Pelaku Vandalisme Ditangkap Dintib. [Accessed 27 January 2019]. http:// jogja.tribunnews.com/2014/06/03/19-pelaku-vandalisme-ditangkap-dintib.

Jennings LB, Parra-Medina DM, Hilfinger-Messias DK, \& McLoughlin K (2008) Toward a critical social theory of youth empowerment. Journal of Community Practice 14 (1-2).

Kemenpora (2009) Undang-Undang Nomor 40 Tahun 2009 tentang Kepemudaan. Jakarta: Kemenpora RI.

Kemenpora (2010) Penyajian Data dan Informasi Statistik Kepemudaan Tahun 2010. Jakarta: Kemenpora RI.

Morton MH \& Montgomery P (2012) Youth empowerment programs for improving adolescents' self-efficacy and self-esteem: A systematic review. Research on Social Work Practice 23 (1):22-33. https://doi.org/10.1177/1049731512459967.

Pearrow MM (2008) A critical examination of an urban-based youth empowerment strategy: The teen empowerment program. Journal of Community Practice 16 (4):509-525. DOI: $10.1080 / 10705420802514213$.

Russell ST, Muraco A, Subramaniam A, \& Laub C (2009) Youth empowerment and high school gay-straight alliances. Journal Youth Adolescence 38 (7):891-903. https://doi.org/10.1007/ s10964-008-9382-8.

Rustinsyah (2018) Women empowerment for poverty reduction in the ring-1 rural area of a cement company in Tuban, East Java Province, Indonesia. Masyarakat, Kebudayaan dan Politik 31 (1).

Sudjana (2004) Pendidikan Nonformal. Bandung: Falah Production.

Sugiyono (2013) Metode Penelitian Pendidikan Pendekatan Kuantitatif, Kualitatif, dan R\&D. Bandung: Alfabeta.

Suparjan \& Suyatno H (2003) Pengembangan Masyarakat dari Pembangunan Sampai Pemberdayaan. Yogyakarta: Aditya Media.

Suharta RB \& Septiarti SW (2018) Pengembangan perlindungan sosial kampong ramah anak di Kota Yogyakarta. Jurnal Pendidikan dan Pemberdayaan Masyarakat 5 (1):9-18. doi:https://doi. org/10.21831/jppm.v5i1.11313.

The Broad Based Education Team (2002) Kecakapan Hidup Life Skills Melalui Pendekatan Pendidikan Berbasis Luas. Jatim: Swa Bina Qualita Indonesia.

Tirtosudarmo (1994) Dinamika Pendidikan dan Ketenagakerjaan Pemuda di Perkotaan Indonesia. Jakarta: Grasindo.

Totok M \& Poerwoko S (2013) Pemberdayaan Masyarakat (Dalam Perspektif Kebijakan Publik). Bandung: Alfabeta. 